\title{
RELATIONSHIP BETWEEN Ig-E LEVELS AND LUNG FUNCTION TESTS IN CHILDREN WITH ASTHMA
}

\author{
BEGUM JA ${ }^{1}$, ISLAM MI ${ }^{2}$, HOQUE SKA ${ }^{2}$, ISLAM MT² ${ }^{2}$, HOSSAIN MZ ${ }^{3}$, MATIN A ${ }^{4}$
}

\begin{abstract}
Background: Asthma is the most common chronic disorder in childhood. A high level of Ig E is associated with asthma.

Objectives: The present study was carried out to observe the relation of serum IgE level with lung function parameters in asthma children and apparently healthy normal children.

Methods: This study was carried out in the out patient department of paediatrics, Dhaka Medical College, Dhaka between January 2010 and June 2010. Total sixty children with age range from six to fifteen years of both sexes were included in this study. Thirty children suffering from asthma and thirty apparently healthy children with no systemic disorder were taken as study population. Serum Ig-E levels were measured in all subjects using a standard Immulite assay by ELISA method. Subjects were classified as having high IgE if their total IgE level was greater than or equal to $100 \mathrm{IU} / \mathrm{ml}$. Subjects were classified as having low IgE if their total IgE level was less than $100 \mathrm{IU} / \mathrm{ml}$. Spirometry was conducted on all patients by using Spirolab a new generation spirometer according to American Thoracic Society standards. Data were analyzed by unpaired test and Chi-squares test.
\end{abstract}

Results: The mean percentage of predicted values of $F E V_{1}, F V C, F E V_{1} / F V C \%$ were significantly lower in high Ig $E(\geq 100 \mathrm{IU} / \mathrm{ml})$ level group in comparison with low Ig $E(<100 \mathrm{IU} / \mathrm{ml})$ group.

Conclusion: Therefore the result of the present study reveals that higher IgE is related with lower lung function and also there were more chance in symptoms based asthma in our study populations.

J Dhaka Med Coll. 2010; 19(1) : 3-6.

\section{Introduction}

Asthma is the most common chronic disorder in childhood. The prevalence of childhood asthma is increasing in both developed and developing countries. ${ }^{1}$ Asthma is characterized by reversible airway obstruction, bronchial hyperresponsiveness (BHR) and atopy. ${ }^{2}$ The relationship between atopy and asthma is not straightforward. Historically atopy has been used as a poorly defined term to refer to allergic conditions such as hay fever, asthma and eczema which cluster in families. Atopy was defined as a positive response to Skin prick test(SPT) -at least one wheal $\geq 3 \mathrm{~mm}$ greater than saline response to a panel of seven aeroallergens or a total serum $\operatorname{IgE} \geq 100 \mathrm{I} \mathrm{U} / \mathrm{ml} .{ }^{3}$ Atopy is a nearly universal finding in children with asthma. Exposure to environmental factors, particularly inhalant allergens is commonly reported as a precipitant of acute exacerbations of asthma. ${ }^{4}$ IgE is an antibody subclass implicated in airway inflammation and allergic reactions. Higher levels of Ig-E are associated with asthma in both adults and children. IgE also may play a role in modulating the severity of asthma, because previous studies have found associations between high Ig-E levels and asthma severity, airway hyperresponsiveness, and lower baseline lung function. ${ }^{5}$ No study so far was done in our country in this topic. So the present study was carried out to observe the relation of serum IgE level with lung function parameters in asthma children and apparently healthy normal children.

1. Associate Professor, Department of Physiology, Ibrahim Medical College, Dhaka

2. Assistant Professor, Department of Paediatrics, Dhaka Medical College, Dhaka

3. Assistant Professor, Department of Medicine, Dhaka Medical College, Dhaka

4. Assistant Professor, Department of Paediatrics, Shaheed Suhrawardy Medical College, Dhaka

Correspondence: Dr. Jesmin Ara Begum 


\section{Methods:}

The present cross sectional study was carried out in the out patient department of paediatrics, Dhaka Medical College, Dhaka from October 2009 to March 2010. The study participants were sixty children of six to fifteen years of age of both sexes. Thirty children suffering from asthma and thirty apparently healthy children with no systemic disorder were taken as study population. Those patients who had experienced asthma symptoms (wheezing, coughing, and /or shortness of breath) in the previous two years were enrolled in your study.

Serum Ig-E levels were measured in all subjects using a standard Immulite assay by ELISA method. Subjects were classified as having high $\operatorname{IgE}$ if their total IgE level was greater than or equal to $100 \mathrm{IU} / \mathrm{ml}$.Subjects were classified as having low IgE if their total IgE level was less than $100 \mathrm{IU} / \mathrm{ml}^{5}$

After selection all the subjects were briefed about the objectives and benefits of the study to ensure their voluntary participation. Informed written consent was taken from each subject prior to the study. After selection all the subjects were asked to attend the department of physiology, Ibrahim Medical College, Dhaka for lung function tests. All relevant information was recorded in a prestructured questionnaire.

Spirometry was conducted on all patients by using Spirolab a new generation spirometer according to American Thoracic Society standards. Subjects with asthma were instructed to withhold their bronchodilator medications for at least eight hours before lung function tests.

Statistical analysis was done using SPSS windows package version 12 . All the data were expressed as Mean \pm SD. The comparisons between two groups were done by unpaired ' $t$ ' test and Chi-square test as applicable.

\section{Results:}

Table -I shows age, weight and height of the study group. Mean \pm SD of age, height and weight in asthma children and in normal children were $7.3 \pm 1.77$ years, $120.6 \pm 12.08$ $\mathrm{cm}, 25.7 \pm 8.82 \mathrm{~kg}$ in case and $8.92 \pm$ 1.93years, $127.27 \pm 8.94 \mathrm{~cm}, 30.4 \pm 7.85 \mathrm{~kg}$ respectively.

Table-I

Characteristics of the study children

\begin{tabular}{lcc}
\hline & $\begin{array}{c}\text { Healthy } \\
\text { children } \\
(\text { Mean } \pm \text { SD) } \\
(\mathrm{n}=30)\end{array}$ & $\begin{array}{l}\text { Asthmatic } \\
\text { children } \\
(\text { Mean } \pm \text { SD }) \\
(\mathrm{n}=30)\end{array}$ \\
\hline Parameters & $8.92 \pm 1.93$ & $7.30 \pm 1.77$ \\
Weight $(\mathrm{kg})$ & $30.40 \pm 7.85$ & $25.70 \pm 8.82$ \\
Height $(\mathrm{cm})$ & $127.27 \pm 8.94$ & $120.60 \pm 12.08$ \\
\hline
\end{tabular}

Table -II shows Ig E level in the study children. High Ig $\mathrm{E}(\geq 100 \mathrm{IU} / \mathrm{ml})$ were found in forty children's among them twenty nine (29) children in asthma cases and eleven (11) in normal populations. Mean \pm SD of Ig-E level in asthma cases and in normal children were $111.57 \pm 94.39$ and $436.73 \pm 465.71$ respectively. As because the mean value was higher in case group compare to control group the difference between them was statistically highly significant.

Table-II

IgE level in the study children

\begin{tabular}{|c|c|c|c|c|c|}
\hline \multirow[t]{2}{*}{$\begin{array}{l}\operatorname{IgE} \\
\text { (IU / ml) }\end{array}$} & \multicolumn{2}{|c|}{$\begin{array}{l}\text { Healthy } \\
\text { children } \\
(\mathrm{n}=30)\end{array}$} & \multicolumn{2}{|c|}{$\begin{array}{l}\text { Asthmatic } \\
\text { children } \\
(\mathrm{n}=30)\end{array}$} & \multirow[t]{2}{*}{$\begin{array}{r}P \\
\text { value }^{\mathrm{a}}\end{array}$} \\
\hline & No. & (\%) & No & $(\%)$ & \\
\hline \multirow[t]{2}{*}{$\geq 100$} & 11 & (36.7) & 29 & (96.7) & \multirow{2}{*}{$0.0001^{* * *}$} \\
\hline & 19 & (63.3) & 1 & & \\
\hline \multirow[t]{2}{*}{ Mean $\pm S D$} & \multicolumn{2}{|c|}{111.57} & \multicolumn{3}{|c|}{$\begin{array}{l}P \text { value } \\
436.73\end{array}$} \\
\hline & \multicolumn{2}{|c|}{ \pm 94.39} & \multirow{2}{*}{\multicolumn{2}{|c|}{$\begin{array}{c} \pm 465.711 \\
38.002000 .00\end{array}$}} & $0.0001^{* * *}$ \\
\hline Range & 32.00 & 420.00 & & & \\
\hline
\end{tabular}

${ }^{\mathrm{a} C h i}$ square test

'Unpaired Student's ' $\mathrm{t}$ ' test

$* * *=$ Significant at $\mathrm{P}<0.001$

Table-III shows relation of High and low Ig E level on lung function test in study population. The mean percentage of predicted values of $\mathrm{FEV}_{1}, \mathrm{FVC}, \mathrm{FEV}_{1} / \mathrm{FVC} \%$ were significantly lower in high Ig $\mathrm{E}(\geq 100 \mathrm{IU} / \mathrm{ml})$ level group in compare to low Ig $\mathrm{E}(<100 \mathrm{IU} / \mathrm{ml})$ group. 
Table III

Relations of IgE level on lung function test outcome in children.

\begin{tabular}{|c|c|c|c|c|c|}
\hline Parameters & Measured & Predicted & Predicted \% & Pvalue & \\
\hline \multicolumn{6}{|l|}{ 1. $\mathrm{FEV}_{1}(\mathrm{~L} / \mathrm{sec})$} \\
\hline $\operatorname{IgE} \geq 100 \mathrm{IU} / \mathrm{ml}$ & 40 & $1.07 \pm 0.47$ & $1.44 \pm 0.47$ & $72.24 \pm 13.04$ & \multirow{3}{*}{$0.008^{* *}$} \\
\hline & & & & & \\
\hline $\operatorname{IgE}<100 \mathrm{IU} / \mathrm{ml}$ & 20 & $1.40 \pm 0.39$ & $1.65 \pm 0.47$ & $84.86 \pm 6.72$ & \\
\hline \multicolumn{6}{|l|}{ 2. FVC (L/sec) } \\
\hline $\operatorname{IgE}{ }^{3} 100 \mathrm{IU} / \mathrm{ml}$ & 40 & $1.21 \pm 0.53$ & $1.63 \pm 0.56$ & $72.92 \pm 12.65$ & \multirow{3}{*}{$0.008^{* *}$} \\
\hline & & & & & \\
\hline $\operatorname{IgE}<100 \mathrm{IU} / \mathrm{ml}$ & 20 & $1.59 \pm 0.46$ & $1.86 \pm 0.56$ & $85.97 \pm 5.81$ & \\
\hline \multicolumn{6}{|l|}{ 3. $\mathrm{FEV}_{1} / \mathrm{FVC}(\%)$} \\
\hline $\operatorname{IgE}{ }^{3} 100 \mathrm{IU} / \mathrm{ml}$ & 40 & $85.78 \pm 5.30$ & $88.85 \pm 3.57$ & $96.72 \pm 7.35$ & \multirow{3}{*}{$0.039^{*}$} \\
\hline & & & & & \\
\hline $\operatorname{IgE}<100 \mathrm{IU} / \mathrm{ml}$ & 20 & $88.56 \pm 3.66$ & $89.03 \pm 2.44$ & $99.49 \pm 3.54$ & \\
\hline
\end{tabular}

Unpaired Student's ' $\mathrm{t}$ ' test

* = Significant at $\mathrm{P}<0.05$

$* *$ Significant at $\mathrm{P}<0.01$

\section{Discussion:}

The results of our analysis demonstrate a relation between high Ig E levels and lung function discrepancies in children with asthma in comparison with apparently healthy children.. In children, there are conflicting results regarding the relationships of asthma severity with serum total Ig E. Even when relationships have been established, the statistical significance achieved is often marginal $(p>0.01)^{6,7}$.The relationship between total serum Ig $\mathrm{E}$ and risk of asthma is well established in children and adults in some sudies. $^{8}$

In the present study, high Ig $\mathrm{E}$ was found in forty children's amongst whom twenty nine were children with asthma and eleven from healthy children. These finding showed that children with asthma mostly having (96.7\%) high Ig E levels. On the other hand children with apparently healthy showed $36.7 \%$ high Ig E levels. Burrows et al demonstrated a similar association between high total serum Ig $\mathrm{E}$ and asthma prevalence in their study. ${ }^{9}$
The data of of our study showed different parameters of lung function test $\left(\mathrm{FEV}_{1}, \mathrm{FVC}\right.$, $\mathrm{FEV}_{1} / \mathrm{FVC}$ ) in relation to Ig E levels. Participant with high Ig E had lower baseline values of $\mathrm{FEV}_{1}, \mathrm{FVC}, \mathrm{FEV}_{1} / \mathrm{FVC} \%$, percent of predicted than did those with low Ig $\mathrm{E}$.

In addition, a greater proportion of study subjects with high Ig $\mathrm{E}$ had $\mathrm{FEV}_{1}<80 \%$ of predicted than did those with low Ig $\mathrm{E}(\mathrm{p}<0.008)$. These results were similarly reported by other workers of different countries. 6,10,11

Although asthma has already been shown to be associated with high serum Ig E levels ${ }^{12}$, our results expand on previous findings by demonstrating that higher Ig E levels were correlated with lower lung function and more severe asthma.

\section{Conclusion:}

Higher Ig E is related with lower lung function and also there were more chance in symptoms based asthma in our study populations. This suggests that, among subjects with asthma with higher Ig E levels the progression to more 
severe asthma may begin early in life. Although these results will need to be confirmed through additional investigation, we conclude that aggressive treatment of atopic patients with asthma may help prevent further decline in lung function over the life time of a child with asthma.

\section{References:}

1. Penny ME, Murad S, Madrid SS, Herrera TS, Pineiro A, et al. Respiratory symptoms, asthma, exercise test spirometry, and atopy in schhool children from a lima shanty town. Thorax 2001; 56:607-12.

2. Leung TF, Wong GWK, Ko FWS, Lam CWK, Fok TF. Clinical and atopic parameters and airway inflammatory markers in childhood asthma: a factor analysis. Thorax 2005;60: 822-6.

3. Carroll WD, Lenny W, Child F, Strange RC, Jones $\mathrm{PW}$, et al. Asthma severity and atopy : how clear is he relationship? Arch Dis Child 2006; 91: 4059.

4. Bacharier LB, Dawson C, Bloomberg GR, Bender B, Wilson L, et al. Hospitalization for asthma: atopic, pulmonary function, and psychological correlates among participants in the childhood asthma management programme. Paediatrics 2003; 112(2): e85-92.

5. Naqvi M, Choudhry S, Tasi HJ, Thyne S, Navarro $\mathrm{D}$ et al. Association between Ig - E levels and asthma severity among African American, Mexican. and Puerto Rican patients with asthma. J Allergy Clin Immunol 2007; 120: 137-43.
6. Siroux V, Oryszczyn MP, Paty E, et al. Relationships of allergic sensitization, total immunoglobulin E and blood eosinophils to asthma severity in children of the EGGEA study . Clin Exp Allergy 2003; 33: 746 -51.

7 . Wever -Hess J, Kouwenberg JM, Duiverman EJ, et al .Risk factors for exacerbations and hospital admissions in asthma of early childhood. Pediatr Pulmonol. 2000; 29: 250-6.

8. Ponsonby AL, Gatenby P, Glasgow N, et al. Which clinical subgroups within the spectrum of child asthma are attributable to atopy? Chest 2002; 121 : 135-42.

9. Burrows B, Martinez F, Halonen M, Barbee R, Cline M, Association of asthma with serum IgE leavels and skin-test reactivity to allergens. N Engl J Med 1989; 320: 271-7.

10. Borish LC, Hipps B, Deniz Y, Gujrathi S, Z heng $\mathrm{B}$, Dolan CM. Total serum IgE levels in a large cohort of patients with severe or difficult to - treat asthma. Ann Allergy Asthma Immunol 2005; 95 : $247-53$.

11. Sears MR, Burrows B,Herbison GP, Flannery EM, Holdaway MD. Atopy in childhood. III. Relationship with pulmonary function and airway responsiveness. Clinical \& Experimental Allergy. 2006; 23(11): 957-963.

13. Sears M, Burrows B, Flannery E, Herbison G, Hewitt C, Holdaway M. Relation between airway responsiveness and serum $\operatorname{IgE}$ in children with asthma and in apparently normal children. N Engl J Med. 1991; 325: 1067 -71. 